\title{
What happened to modern Irish urban history?
}

\author{
DAVID DICKSON \\ Department of History, Trinity College, Dublin 2, Ireland
}

\begin{abstract}
A remarkable cluster of Irish town histories appeared in the early nineteenth century, coming after several generations of unprecedented urban growth. But that growth stalled and most Irish towns entered a long period of stagnation. Meanwhile, academic interest in the urban past became dormant. Urbanization in Ireland resumed in the twentieth century, but the study of urban history was late to develop and slow to move beyond the documentation of built heritage. However, public interest in medieval origins, official interest in urban heritage and the vision of a handful of medieval historians and historical geographers have helped transform the prospects for Irish urban history.
\end{abstract}

Scholarly work on Irish urban history - outside the confines of architectural history - has gained little critical notice, either within Ireland or outside it. This reflects the fact that published output in the field has been modest enough. It is instructive to try and find out why. Is it because Ireland has only recently become a predominantly urban society, one that therefore feels little connection with or public interest in the urban past? Urban roots are certainly not as deep in Ireland as in the neighbouring island, where the urban legacy of long incorporation into the Roman empire was never completely lost. Yet several Irish towns have celebrated the supposed millennium of their foundation, suggesting that by wider Atlantic standards, Irish urban roots are certainly not shallow. However, because these roots are linked to Viking aggression and AngloNorman colonialism, much of the writing on early Irish towns has been narrowly focused on whether their form and composition were indigenous or colonial, leaving other aspects of their evolution aside. ${ }^{1}$ And the later history of urban formation and growth has been heavily subsumed within the narrative of the rise, fall and rise again of English power in Ireland. Towns were indeed a central element in the projection and elaboration of that power, whether in the thirteenth or the seventeenth centuries, and the persistence of religious conflict within Irish urban communities in the

${ }^{1}$ L.J. Proudfoot, Urban Patronage and Social Authority: The Management of the Duke of Devonshire's Towns in Ireland, 1764-1891 (Washington, DC, 1995), 11-12. 
eighteenth and nineteenth centuries was a long-burning consequence of that old colonial function.

One might therefore assume that such a troubled history, the wholesale displacement of urban elites in the seventeenth century and the systematic discrimination that persisted through much of the eighteenth, would have effectively destroyed any sense of local urban identity or of shared history. In an exemplary exercise in comparative history, Rosemary Sweet has found how the vigorous production of town histories in seventeenth- and eighteenth-century England found no parallel in contemporary Ireland and has argued that this reflected deep differences in urban culture. ${ }^{2}$ What is perhaps more surprising is how this situation changed shortly after 1800 when there was a sudden flush of historical works on Irish towns. One of the most reflective works was a history of the town of Galway, published in Dublin in 1820. Its author, James Hardiman - lawyer, archivist, antiquarian and pioneering folklorist - presented it to his readers as a work of revelation, demonstrating the rich and heretofore hidden antiquity of 'the capital of Connaught', an urban world brought low over the previous two centuries by penal laws against Catholics and by English mercantilist legislation that only now, in a more enlightened age, was entering a renaissance. Hardiman noted the extraordinary absence of urban history-writing in Ireland compared to Britain, where 'almost every village and hamlet...can boast of its history'. ${ }^{3}$ Yet within a few years, his Galway history shared the shelf with Warburton, Whitelaw and Walsh's Dublin (1818), and with seven other Irish urban histories. These were substantial antiquarian and topographical works, but unlike the contemporaneous Irish county statistical surveys that were sponsored by the Dublin Society, their publication was not in any way co-ordinated. And it is striking that their authors were all local men, drawn from across the religious spectrum. None was unduly partisan, pride of place it seems masking the divisive passions of the age. But the fashion passed, and even with the revival of topographical antiquarianism in the later nineteenth century few of the concerns of urban history received much notice. ${ }^{4}$

2 R. Sweet, 'Provincial culture and urban histories in England and Ireland during the long eighteenth century', in P. Borsay and L. Proudfoot (eds.), Provincial Towns in Early Modern England and Ireland: Change, Convergence and Divergence (Oxford, 2002), 223-39.

${ }^{3}$ J. Hardiman, The History of the Town and County of the Town of Galway... (Dublin, 1820), v-viii.

${ }^{4}$ J. Warburton, J. Whitelaw and R. Walsh, History of the City of Dublin..., 2 vols. (London, 1818); S. McSkimin, The History and Antiquities of the County and Town of Carrickfergus... (Belfast, 1811); J. Stuart, Historical Memoirs of the City of Armagh... (Newry, 1819); [G. Benn], The History of the Town of Belfast... (Belfast, 1823); R.H. Ryland, The History, Topography and Antiquities of the County and City of Waterford (London, 1824); L.C. Johnston, History of Drogheda... (Drogheda, 1826); P. Fitzgerald and J.J. McGregor, The History, Topography, and Antiquities, of the County and City of Limerick, 2 vols. (Dublin, 1826-27); F.H. Tuckey, The County and City of Cork Remembrancer... (Cork, 1837). Benn's history of Belfast was the only one to be re-issued later in the nineteenth century. The most notable late nineteenthcentury additions to Irish urban history were the publication of the records of a number of the unreformed municipal councils - Dublin, Cork, Belfast, Galway, Youghal and Kinsale. 
The irony is that the moment of optimistic self-reflection in the early years of Anglo-Irish union that was exemplified by Hardiman marked not so much a renaissance but the closing stages of a long period of urban regeneration. In the case of largest Irish cities, Dublin and Cork, the process of physical and demographic growth had commenced during the seventeenth century, concurrent with the elaboration of English mercantilist legislation; in the case of other Irish port cities, the county towns and the regional centres, urban growth only became the prevailing trend from the middle years of the eighteenth century, when of course formal religious discrimination was still in full force. Hardiman was right to talk of the eclipse of early modern Galway, but wrong to characterize it in primarily political terms. And now in the 1820s, with Anglo-Irish free trade and currency union being fully implemented and with the last stage of Catholic emancipation on the cusp of achievement, Hardiman's optimism was to prove misplaced. The tide would recede once again for Galway and indeed for most of the other larger Irish towns. They were close to their maxima in terms of population, reaching a human scale not to be surpassed in some cases until the second half of the twentieth century.

By the time of the first completed census in 1821, the proportion of Ireland's population recorded as living in towns and cities of more than 2,000 inhabitants (a low threshold of urbanization) reached 13.5 per cent. It was virtually unchanged 20 years later in 1841 . Thereafter, the urban share rose in each decennial census to reach 33.5 per cent by 1911. But that of course masks the fact that national population was declining throughout the period from the time of the Great Famine, and that urban population loss was rather less than that occurring in the countryside. Thus, 99 of the 139 towns and cities that had a population of 2,000 or more in 1841 were actually smaller 70 years later in 1911. Urban population recovery over much of the country only resumed in the 1930s, and in some cases not until the 1960s. ${ }^{5}$

The striking under-emphasis of the urban dimension in Irish social history reflects this long demographic stagnation. Nineteenth-century change, whether for good or ill, was evident primarily in the countryside, and the distant eighteenth-century cycle of urban growth was obscured by the subsequent prolonged stasis, in complete contrast to the almost explosive growth of cities across much of western Europe after the 1870s. There were of course regions of slow urban growth in every country, but the Irish pattern seems to have been unusually intense and enduring. Admittedly, the physical fabric of nineteenth-century Irish towns and cities changed a great deal what with the expansion of urban sites, the slow improvement of utilities, the renewal of housing stock and a far richer diversity of public and commercial buildings. But the prevailing assumption in much of the historiography has been that Irish towns and

5 See D. Dickson, 'Town and city', in E. Biagini and M. Daly (eds.), The Cambridge Social History of Modern Ireland (Cambridge, 2017), 112-28. 
cities, such as they were, had relatively weak agency, whether in terms of the political struggle, the devotional revolution, the language shift or the wider modernization of cultural practices and material comforts. And in the nationalist narrative, towns with their pervasive Protestant and anglicizing legacies were places to be conquered or, at best, were no more than passive sites of contention in the long rise of Irish democracy and self-determination. Compounding this strain of anti-urbanism in the early twentieth century, Catholic writers linked Irish city life with moral degeneracy, socialism, atheism and the horrors of communism. It took the distinctive pen of a Protestant nationalist, Stephen Gwynn, to provide the first balanced and quite sympathetic history and guidebook to Irish cities; it appeared in $1915 .^{6}$

\section{Rebirth of an Irish urban history}

And so to modern urban history making. In 1979, amidst the Troubles, the then quite prestigious Irish Conference of Historians met in Queen's University Belfast for its biennial conference to debate 'The town in Ireland'; the proceedings appeared two years later, edited by David Harkness and Mary O'Dowd. Unlike most such events, all the papers were on Ireland and nearly all were by Irish-based historians (Geoffrey Martin of Leicester being the sole English contributor). It was an impressive lineup, and nearly four decades later, it still generates citations. Despite some lamentations by the Belfast conference organizers about how the study of the town in Ireland having been 'too long neglected, distinguished though a few limited studies have been', Irish urban history was it seems coming back into the sunlight. ${ }^{7}$

The previous few years had witnessed an extraordinary set of events in and around Dublin's Wood Quay that lay within the old walled city, a battle between the city corporation, impatient to execute its grandiose plans for a set of brutalist civic offices, and a motley coalition of archaeologists, medieval historians, writers and students, determined to secure the Viking and post-Viking site from destruction. The battle culminated - again in June 1979 - in Operation Sitric and a three-week occupation of the site. At its peak, some 20,000 people had marched in Dublin to protest at the city corporation's dogged determination to pour concrete on the uniquely rich tenth- to thirteenth-century alluvial deposits that promised to illuminate the life of the first dozen generations of Dubliner. And even when the emergency dig was finally ended in 1981, that combination of public fascination in the material culture revealed in the mudbanks and of public anger at a car-obsessed municipal

${ }^{6}$ S. Gwynn, The Famous Cities of Ireland (Dublin, 1915).

7 D. Harkness and M. O'Dowd (eds.), The Town in Ireland (Belfast, 1981), 1. It was a reflection of research in the 1970s that five of the ten published papers related to Ulster, three of them to Belfast. 
bureaucracy went on to have political consequences at the next local government elections. Thus began the slow discovery of 'heritage' by Dublin Corporation, leading to a fictitious choice of 1988 as the city's millennium, to plans (unfulfilled) for a city museum and of course to the monumentalization of the city's spirit in the buxom statue of Molly Malone. $^{8}$

Wood Quay was a turning point in the attitude of the Irish public to the urban past. The protest leaders, a group of intrepid medieval historians and geographers based in University College Dublin (UCD), were already pioneers in the promotion of urban history, coming at the time when a number of other Irish historical geographers, at the peak of their career, were busily promoting post-medieval urban research in less dramatic ways. ${ }^{9}$

Around the time of the protests, several of the Wood Quay leaders were also involved in a rather different kind of initiative - the Irish Historic Towns Atlas (IHTA) project. Two of the founders of the Atlas were of English background, Howard Clark and John Andrews, and the third was the German-born Anngret Simms, and they secured some very modest public funding to launch this highly ambitious project in 1981, based as it was on a European template developed by the International Commission for the History of Towns. They promised to publish fascicles for 'a selection [of Irish cities and towns] representing various size-categories, [and] various regions of the country'. Now 37 years later, the founding group has only just stepped down; 25 town atlases have been published in whole or in part, and a further 17 are 'in progress'. ${ }^{10}$

\section{Fin de siècle}

Jim Dyos, for all his extraordinary championing of urban history, seems to have had no particular interest in Irish urban history to judge by the electronic catalogue of his papers. He was admittedly taking photographs in pre-Troubles Belfast in 1967, presumably when the Urban History conference, attached then to the Economic History Conference, was being held in Queen's University, an event that lead to the establishment of an Economic and Social History of Ireland but not to an Irish urban history society, or even to a formal Irish offshoot of Dyos' enterprise. The one Irish historian with whom he did correspond was Sybil Baker, whose chapter on

8 J. Bradley (ed.), Viking Dublin Exposed: The Wood Quay Saga (Dublin, 1984); D. Dickson, Dublin: The Making of a Capital City (London, 2014), 559-63. The definitive report on these excavations appeared only recently: P. Wallace, Viking Dublin: The Wood Quay Excavations (Dublin, 2015).

${ }^{9}$ Notably the contributions of John Andrews, Joseph Haughton and Nuala Burke in Trinity College Dublin, and of T. Jones Hughes in UCD (whose writings were gathered posthumously in T. Jones Hughes, Landholding, Society and Settlement in Nineteenth-Century Ireland: A Geographer's Perspective (Dublin, 2010)).

10 See introduction to J.H. Andrews (ed.), Kildare (IHTA fascicle 1) (Dublin, 1986); https:// www.ria.ie/research-projects/irish-historic-towns-atlas. 
Edwardian Belfast was the sole Irish entry in his canonical two-decker, The Victorian City (1973). She was indeed one of the stars of the 1979 conference in Belfast, but present there were other regular Irish veterans of the Urban History conferences held in Britain, most notably W.H. (Bill) Crawford, then education officer in the Public Record Office of Northern Ireland. Crawford's lifelong evangelical enthusiasm for urban history, fed by his insider's knowledge of the riches of Public Record Office, was perhaps coloured by the toxic political climate in the world outside. 'Gas and water' social history had its cross-community attractions. Some excellent local urban studies across Ulster were quietly germinated by Crawford's advocacy. ${ }^{11}$

Urban history was also promoted by two series of conferences that commenced in the late 1970s, one involving French and Irish social and economic historians, the other historians from Scotland and Ireland. The common link was Louis Cullen, based in Trinity College Dublin, and the proceedings of most of these pioneering conferences were subsequently published. Urban history featured particularly strongly in the Franco-Irish colloques, notably in Cities and Merchants (1986). ${ }^{12}$ However, there was more truly comparative work in the some of the later Irish-Scottish conferences, most explicitly in the five papers comparing aspects of Scottish and Irish urbanization between the seventeenth and twentieth centuries that formed part of Conflict, Identity, and Economic Development (1995). ${ }^{13}$

Thus, when Mary Daly, who had recently published the first social history of Victorian Dublin, came to assess the general state of Irish urban history for the Urban History Yearbook in 1986, she was decidedly upbeat about the prospects, although noting some dark areas, not least that 'Irish urban history post-1914 is totally unexplored.' ${ }^{14}$ Three decades later, that glaring absence is no longer true, but was the momentum, or at least the promise, so evident in the 1980s sustained? At first sight, the answer is a positive. Publications in Irish urban history continued over following decades, a respectable if not spectacular flow of material. Yet when set against the exponential development of European, American and international urban historiography over the last 30 years, most work in

11 S.E. Baker, 'Orange and Green: Belfast, 1832-1912', in H.J. Dyos and M. Wolff (eds.), The Victorian City: Images and Realities, 2 vols. (London, 1973); www2.le.ac.uk/departments/ urbanhistory/research/dyos. For Crawford's publications: B. Collins, P. Ollerenshaw and T. Parkhill (eds.), Industry, Trade and People in Ireland, 1650-1950: Essays in Honour of W.H. Crawford (Belfast, 2005), 277-80.

12 P. Butel and L.M. Cullen (eds.), Cities and Merchants: French and Irish Perspectives in Urban Development, 1500-1900 (Dublin, 1986). See also essays in L.M. Cullen and P. Butel (eds.), Négoce et industrie en France et en Irlande aux XVIIIe et XIXe siècles (Paris, 1980).

13 S.J. Connolly, R.A. Houston and R.J. Morris (eds.), Conflict, Identity, and Economic Development: Ireland and Scotland, 1600-1939 (Preston, 1995). See also essays in T.M. Devine and D. Dickson (eds.), Ireland and Scotland, 1600-1850: Parallels and Contrasts in Economic and Social Development (Edinburgh, 1982).

14 M.E. Daly, 'Irish urban history: a survey', Urban History Yearbook 1986 (Leicester, 1986), 68; M.E. Daly, Dublin, the Deposed Capital: A Social and Economic History, 1860-1914 (Cork, 1984). 
Ireland was episodic, uneven and disjointed, whether in terms of period, topic or methodology.

Urban case-studies were, however, beginning to proliferate, thanks to two indigenous publication projects. The first was the Geography Publications series of composite Irish county histories that began to appear in 1985. Remarkably, this was a private initiative, taken by another UCD historical geographer, William Nolan. By 2016, with three-quarters of Irish counties covered in some 670 chapters, much fascinating new research has come to light. However, it is perhaps telling that only about a tenth of the essays in the county volumes are specifically urban in focus, with the volumes for counties Waterford and Limerick contributing a disproportionately high number of the urban chapters. ${ }^{15}$ The second project was the Maynooth Local Studies pamphlets begun in 1995, which by mid-2016 had created a library of 127 titles. Here, the urban dimension comes through more strongly: nearly a third of the titles are urban in focus; nearly all are post-medieval, and the majority relate to nineteenthor twentieth-century topics, incidents or persons, set against small town or village settings in many cases. ${ }^{16}$

There was admittedly some hint of theory and of international intellectual currents at the twin symposia on urban history organized by British Academy and Royal Irish Academy in 1998, the first on early modern London and Dublin, the second on provincial towns in early modern England and Ireland. The architects of these colloques were Peter Clark in Leicester and Raymond Gillespie in Maynooth, both early modernists of broad urban vision, and the published proceedings contained some tantalizing reflections on the differences between English and Irish pre-industrial urbanization. ${ }^{17}$ Peter Borsay and Lindsay Proudfoot were diplomatic when introducing the second volume: Irish urban history was still defined, they reckoned, by 'its emphasis on urban morphology and, overwhelmingly, [on] narrative biographies of individual settlements, and [by] the relative scarcity of attempts to establish a theoretical base for the study of historical urbanism in Ireland'. ${ }^{18}$ But one can detect in Peter Clark's subsequent magisterial survey, European Cities and Towns, 400-2000 (2009), the incorporation, really for the first time, of Irish urban development into a Europe-wide synopsis. It is true that Irish cities had featured in Jan de Vries' 1984 study of the demography of pre-industrial European cities, but despite his finding that Irish cities had roared up the population rankings during the eighteenth century, he offered no particular explanation for this. Clark by contrast

15 These are my estimates based on the contents lists of 'History and Society' titles on the geographypublications.com website.

16 The series is listed at www.maynoothuniversity.ie/history/past-theses.

17 P. Clark and R. Gillespie (eds.), Two Capitals: London and Dublin, 1500-1840 (Oxford, 2001); Borsay and Proudfoot (eds.), Provincial Towns.

18 P. Borsay and L. Proudfoot, 'The English and Irish urban experience, 1500-1800: change, convergence and divergence', in Borsay and Proudfoot (eds.), Provincial Towns, 7. 
made good use of Irish (and Scottish) evidence to identify what he called an 'outer Northern Europe' urban region, a classification that works quite well as a heuristic device, at least up until the early nineteenth century. ${ }^{19}$

During Clark's tenure of the chair of Urban History in Leicester, he was co-ordinator of an early EU-funded research project, EUROCIT (199396), and Ireland, specifically UCD, was one of the partners involved: the key Irish output was a 250-page guide to urban history sources that was dedicated 'to all men and women, who have committed themselves to research the rich heritage of Irish towns. It is intended to be their companion on an exciting but often difficult journey of discovery. ${ }^{\prime 20}$ In other words, it was aimed at the local historian, and one detects here the voice of the inimitable Anngret Simms. The guide included a bibliography of publications on Irish towns across the years 1500 to 1980 published over the previous 25 years which ran to 48 pages; nearly three-quarters of the entries related to individual towns. The bibliography was, however, a rather odd piece of work, arbitrary in its categorizations, and it included a catch-all section of some 90 items on 'Urbanization: settlement and society', essentially a listing of comparative essays. All very impressive, but perhaps more a tribute to the impossibility of defining the boundaries or indeed the purpose of urban history than a benchmark of progress.

But the big urban story in the 1990s came from the north, from Brian Graham and Lindsay Proudfoot, then in the University of Ulster and Queen's University. First, they brought to press An Historical Geography of Ireland (1993), a volume of great originality that included, apart from their own short reflections on Irish urbanization, a pioneering chapter by Stephen Royle on 'Industrialization, urbanization and urban society, c. $1850-1921^{\prime}{ }^{21}$ And a little later, they secured the first large-scale funding for a specific Irish urban history project, a Leverhulme grant to investigate 'Landlords and urbanisation in eighteenth- and nineteenthcentury Ireland'. The project resulted in two short (and obscurely published) booklets, a handful of published essays and a set of databases. Graham and Proudfoot, together with their research assistant Susan Hood, developed important arguments on agency in urban development, playing down the role of the landed proprietor in the shaping and managing of post-medieval Irish towns. Here, they were taking up an argument first put forward by Arnold Horner, based on his work on the Leinster estate in Kildare. ${ }^{22}$ But it was Proudfoot's fine monograph Urban Patronage

19 J. de Vries, European Urbanization, 1500-1800 (London, 1984), 280; P. Clark, European Cities and Towns, 400-2000 (Oxford, 2009), 5.

20 W. Nolan and A. Simms, Irish Towns: A Guide to Sources (Dublin, 1998), 2.

21 S.A. Royle, 'Industrialization, urbanization and urban society in post-Famine Ireland, c. 1850-1921', in B.J. Graham and L.J. Proudfoot (eds.), An Historical Geography of Ireland (London, 1993), 258-92.

22 L.J. Proudfoot and B.J. Graham, 'The nature and extent of urban and village foundation and improvement in eighteenth- and nineteenth-century Ireland', Planning Perspectives, 8 (1993), 259-81; idem and idem, Urban Improvement in Provincial Ireland, 1700-1840 (Athlone, 
and Social Authority (1995) on the development of the Devonshire estate towns in Munster that got far more critical attention than the Leverhulme project - and it was making a rather different point: that there were some Irish estate owners, those with exceptionally deep pockets and political ambitions like the Devonshires, who did make a huge and enduring impact on the physical evolution of their towns. ${ }^{23}$ The subtlety of the wider message and their larger survey may have got lost somewhere.

\section{Delivery delayed}

From the late 1990s, new work on Irish urban history became thinner. In the annual Irish Economic and Social History, where there had been at least one urban-centred paper each year through the 1990s, this fell away to a handful in the next decade. Many of those whose primary interest was urban history were nearing retirement were over-committed or (like Proudfoot) were moving off in other directions, and the number of doctoral students working in the field was quite small. Historical geography was beginning its long eclipse. Research funding for the Humanities and Social Sciences in the Republic of Ireland was becoming available for the first time at the end of the 1990s, yet there was no specific urban history project seeking large-scale funding. Admittedly, UCD's Urban Institute of Ireland did receive major investment at this time, but those with an interest in the urban past were not heavily involved. Simms and her departmental colleague Joseph Brady did, however, launch at that stage what was a fairly in-house UCD project: a series of volumes entitled 'The Making of Dublin', the first volume of which spanned a thousand years of the capital's history in six chapters; the subsequent five volumes in the series have all been monographs exploring in close detail the physical development of the twentieth-century city. ${ }^{24}$

The modest output after 2000 of what was identifiably urban history stood in contrast to the pronounced growth of public interest in Irish urban heritage - witness the huge numbers that the Friends of Medieval Dublin regularly attracted to the annual conference every May since 1999, or the local enthusiasm when the fascicle for their town was launched by the IHTA project. The small number who completed doctoral dissertations in Irish urban history found it extremely difficult to get publishers interested - unless there were lots of maps and pretty pictures - and

1994); L. Proudfoot, Property Ownership and Urban and Village Improvement in Provincial Ireland, c. 1700-1845 (Edinburgh, 1997); idem, 'Markets, fairs and towns in Ireland, c. 16001853', in Borsay and Proudfoot (eds.), Provincial Towns, 69-96; A. Horner, 'The scope and limitations of the landlord contribution to changing the Irish landscape, 1700-1850', in Collected Papers Presented to the Permanent European Conference for the Study of Rural Landscape (Copenhagen, 1986).

23 Proudfoot, Urban Patronage.

24 J. Brady and A. Simms (eds.), Dublin through Space and Time, c. 900-1900 (Dublin, 2001). For subsequent titles in this series published and forthcoming: www.fourcourtspress.ie/ books/archives/dublin-19101940/related. 
recycled narrative histories of the main cities, notably of Dublin itself, continued to weigh down the bookshelves.

The absence of a healthy crop of monographs reflected in a general way the marginalization across all Irish universities of the constituent disciplines that had promoted urban historical research: historical geography (once very strong); economic history (never strong but once full of lusty promise); business history (an almost empty field); and architectural history, in a continuing cinderella state despite the productivity of a few. ${ }^{25}$ But one wonders whether the limited visibility of published research was not exacerbated by the fact that scarce expertise and energy were committed over many years to projects with a low academic profile and low impact in the world outside, whether it has been the lengthy contributions published in Geography Publication's county histories, the bespoke essays in the Maynooth Local Studies series or the huge editorial input to the IHTA project. In the case of the Atlas, although each fascicle had to have a (strictly defined) introductory essay, very considerable intellectual effort has gone into the topographical inventories and in the interpretation of the accumulated cartography of the 24 favoured towns and cities. It has been a very considerable intellectual investment that will only achieve the kind of impact it deserves when a digital format is fully adopted and when it becomes an open-access resource (a pilot project is currently underway).

One of the undoubted successes of the IHTA team was their ability to draw financial support from local public authorities, notably from Derry/ Londonderry, Belfast and Dublin city councils for their respective atlases. Derry, Belfast and Cork councils have in recent times also subvented ambitious multiauthored city histories, notably John Crowley's visually spectacular Atlas of Cork City (2005), which incorporates no less than 59 contributors, and Sean Connolly's far tighter collection of nine essays, Belfast 400 (2012). ${ }^{26}$ And Dublin city council, to wipe its face in heritage matters, has since 2000 helped to underwrite the cost of the 16 volumes of Medieval Dublin that have brought together the annual proceedings from the previous year. But the city authorities in Waterford have gone further and done what larger cities, including Dublin, have signally failed to do:

25 There has been a marked growth over the last decade of publications on the twentiethcentury architectural history and urban design of Dublin, and also a smaller number of important contributions with a wide chronological scope including C. Casey, Dublin (London, 2005); N. McCullough, Dublin: An Urban History, 2nd edn (Dublin, 2007); and R. Usher, Protestant Dublin, 1660-1760: Architecture and Iconography (Basingstoke, 2012). Additionally, several 'ancillary volumes' have been published by the IHTA, including C. Lennon and J. Montague, John Rocque's Dublin: A Guide to the Georgian City (Dublin, 2010); and F. Cullen, Dublin 1847: City of the Ordnance Survey (Dublin, 2015).

26 J.S. Crowley, R.J.N. Devoy, D. Linehan and P. O'Flanagan (eds.), Atlas of Cork City (Cork, 2005); R. Gavin, W.P. Kelly and D. O'Reilly, Atlantic Gateway: The Port and City of Londonderry since 1700 (Dublin, 2009); S.J. Connolly (ed.), Belfast 400: People, Place and History (Liverpool, 2012). 
to invest in a proper city museum (three venues in fact), and they have drawn very effectively on local archaeological and historical expertise. ${ }^{27}$

Another explanation for the apparent eclipse of urban history is more benign: that it has simply been masquerading under other banners whether in the proliferating studies of print culture in Ireland, best captured in the multivolume Oxford History of the Irish Book, or in the (late) arrival in Ireland of the cultural history of consumption: the latter has led to a wave of highly innovative studies since 2000 by Flavin, Barnard, Powell, Fitzgerald, Rains, Clarkson and Crawford among others, which between them span four centuries and examine the many dimensions of material culture. The evidence and intellectual focus of this corpus of work has been primarily on urban society - or on elites. ${ }^{28}$ How it will feed into wider debates on the cultural impact of urbanization and of the urban environment on long-term Irish social, demographic, religious and political change remains unclear.

So what now? There have been some admirable examples of what Irish urban history might become in the late A.C. Hepburn's work, notably in his short but magnificent final tour de force, Contested Cities in the Modern West (2004), drawing inter alia on his lifelong work on Belfast, or in R.J. Morris' theoretically nuanced and scintillating essay on the place of urbanization in the history of Ulster. ${ }^{29}$ There is no shortage of unexplored issues to tease out if we are to determine what was distinctive in Irish urban evolution, whether it is its historical depth, its singular periodization, its ambiguous coloniality or its unanticipated contemporary outcomes. Perhaps now is the time to be ambitious again and to recapture the optimism, whether of Hardiman's Galway in 1820 or Harkness's Belfast in 1979.

27 See www.waterfordtreasures.com.

28 S. Flavin, Consumption and Culture in Sixteenth-Century Ireland: Saffron, Stockings and Silk (Woodbridge, 2014); M.J. Powell, The Politics of Consumption in Eighteenth-Century Ireland (Basingstoke, 2005); T. Barnard, Making the Grand Figure: Lives and Possessions in Ireland, 1641-1770 (New Haven, 2004); A. Fitzgerald, Silver in Georgian Dublin: Making, Selling, Consuming (London, 2016); S. Rains, Commodity Culture and Social Class in Dublin, 18501916 (Dublin, 2010); L.A. Clarkson and E.M. Crawford, Feast and Famine: A History of Food and Nutrition in Ireland, 1500-1920 (Oxford, 2001).

29 A.C. Hepburn, Contested Cities in the Modern West (Basingstoke, 2004); R.J. Morris, 'Urban Ulster since 1600', in L. Kennedy and P. Ollerenshaw (eds.), Ulster since 1600: Politics, Economy and Society (Oxford, 2013), 121-39. 